\title{
Distinguishing Creeping Bluegrass (Poa annua var. reptans) Genotypes Using Inter-simple Sequence Repeat Markers
}

\author{
Troy D. Carson, Donald B. White, and Alan G. Smith ${ }^{1}$ \\ Department of Horticultural Science, University of Minnesota, \\ 1970 Folwell Avenue, St. Paul, MN 55108
}

Additional index words. Poa supina, Poa trivialis, molecular markers

\begin{abstract}
Poa annua L. has long been a cultivated weed on golf courses. However, the recent development of improved cultivars of creeping bluegrass (Poa annua reptans Hausskn.) has generated an increasing interest in selection and breeding of this species. Inter-simple sequence repeat (ISSR) PCR is a relatively new method for genotype identification and measuring genetic diversity and was employed in this study for differentiating among creeping bluegrass genotypes. The objectives of this study were to test ISSR primers for production of polymorphic fragments and ascertain the applicability of ISSR PCR to distinguish closely related genotypes. Eight primers produced fragments, of which $\mathbf{7 7 . 3 \%}$ were polymorphic, and primers UBC849, UBC850, and UMN001 produced over $75 \%$ of the total polymorphic fragments. These three primers had sufficient resolution to distinguish all but two of the diploid creeping bluegrass accessions. This method was a simple, fast, and relatively inexpensive method to produce useful DNA fragments in creeping bluegrass. It is a robust method for detecting polymorphic loci that can be used in the study of genetic relatedness, heritability, or linkage to important traits, development of linkage maps, and markerassisted breeding.
\end{abstract}

Poa annua L. is a ubiquitous cool-season turfgrass that is reported to have originated on the European continent (Tutin, 1957). It is an allotetraploid $(2 \mathrm{n}=4 \mathrm{x}=28)$ thought to be derived from a chance cross between Poa infirma Kunth and Poa supina Schrader (Darmency and Gasquez, 1997; Nannfeldt, 1937; Tutin, 1952, 1957). P. infirma is an erect, bunch-type, diploid $(2 \mathrm{n}=2 \mathrm{x}=14)$ annual, whereas $P$. supina is a prostrate, stoloniferous, diploid $(2 \mathrm{n}=2 \mathrm{x}=14)$ perennial (Tutin, 1957). P. annua has a continuum of life-cycle types that include true annuals to long-lived perennials as well as numerous variants between the two (Gibeault, 1971; Heide, 2001; Johnson et al., 1993; Timm, 1965). The life cycle forms of $P$. annua at its extremes have been divided into two types: the annual, designated $P$. annua var. annua (L.) Timm, and the perennial, P. annua var. reptans (Hauskn.) (Timm, 1965). The common name for $P$. annua, annual bluegrass or annual meadowgrass, is a misnomer for the

Received for publication 4 May 2006. Accepted for publication 22 June 2006.

We thank Jon Powell for his advice and use of laboratory equipment and Brian Horgan for his assistance.

This research was funded in part by the Minnesota Agricultural Experiment Station and is Minnesota Agricultural Experiment Station Paper No. 015210148.

${ }^{1}$ To whom correspondence and reprint requests should be addressed; e-mail smith022@umn.edu. perennial type considering it is not an annual. To alleviate the confusion, the perennial type, $P$. annua var. reptans, was assigned the common name creeping bluegrass (Beard, 1999), as reptans means "creeping" (Bailey, 1948), while annual bluegrass remains the common name for P. annua var. annua. In addition to the tetraploid form, $P$. annua also exists as a sterile diploid but generally only on putting greens. Velguth and White (1993), in Minnesota, discovered that $24 \%$ of randomly collected $P$. annua plants from selected putting greens were diploid.

$P$. annua is an economically important turfgrass that has often been ignored even though it is the predominate turfgrass on many of the most prestigious golf courses around the world, including many of the courses that have hosted U.S. Open golf tournaments (Baker et al., 1995; Huff, 1999; Wu et al., 1987). It is particularly well adapted to extremely low heights of cut (3$4 \mathrm{~mm}$ ), compacted soil, and shade; conditions common to golf course greens and tees. $P$. annua has long been considered an unwanted weed in highly maintained turfgrass surfaces (Beard, 1970; Kamp, 1981; Sprague and Burton, 1937); however, others view $P$. annua as a cultivated invader that has performed as well as, if not better than, the planted species. While the former have long attempted to rid the turf of this so-called weed, the latter have believed it best to manage the species most favored in a particular ecosystem (Beard et al., 1978).
Researchers have recognized the attributes of creeping bluegrass that make it a desirable turfgrass surface: perennial, stoloniferous, high tiller density, shade-tolerant, rapid germination, dark color, and limited flowering period (Adams and Bryan, 1980; Johnson et al., 1993; Sprague and Burton, 1937; Timm, 1965). Plant breeders are now accumulating breeding populations, making crosses, and developing cultivars for commercial release (Kind, 1997). To improve breeding and selection for desirable traits, a technique that would accurately differentiate and identify closely related genotypes would be useful. Such a technique could prove useful for legal protection of cultivars in addition to phenotypic data, which can be affected by environmental factors, and could also find utility for marker-assisted selection.

The biological, morphological, and ecological characteristics that influence the distribution of different $P$. annua types have been investigated (Law et al., 1977; Warwick and Briggs, 1978a, 1978b). Others have examined the genetic relatedness of various populations in differing environments through the use of molecular markers. Darmency et al. (1992) and Darmency and Gasquez (1997) investigated the inheritance of isozyme patterns, and Cline (2001), Mengistu et al. (2000), and Sweeney and Danneberger (1995) used random amplified polymorphic DNA (RAPD) markers to study the relationship of wild $P$. annua collections. These studies looked at diversity or population relationships of wild $P$. annua collections within a given environment and different environments on a single golf course; however, no one has studied the genetics of closely related genotypes within a breeding program.

PCR analysis using anchored SSR or ISSR has been reported to be a useful and reliable method of detecting genetic polymorphisms between accessions (Zietkiewicz et al., 1994) and has been used in cultivar identification in many crops, including wheat (Nagaoka and Ogihara, 1997), maize (Kantety et al., 1995), potatoes (Prevost and Wilkinson, 1999), Douglas-fir (Tsumura et al., 1996), and barley (Fernandez et al., 2002). The ISSR PCR method uses di-, tri, tetra-, or pentanucleotide repeats with a one-, two-, or three-base tag attached to the $3^{\prime}$ or $5^{\prime}$ end of the repeat. The tag assures that the primer anneals to the end of the simple sequence repeat and thus provides greater specificity.

The benefit of using ISSR PCR over other methods include greater specificity and repeatability than RAPD, reduction in preparation time over AFLP because there is no need to use restriction enzymes, no requirement for prior knowledge of the target sequence as with SSRs, visualization of PCR products on an agarose gel, and relatively low cost.

This study examined the utility of ISSR PCR for genotyping creeping bluegrass accessions within the University of Minnesota breeding program. Previous molecular 
marker work with Poa annua has only been done with wild plant collections, while no one has looked at closely related genotypes. The objectives of this study were to test ISSR primers for production of polymorphic fragments and to ascertain the applicability of ISSR PCR to distinguish closely related genotypes.

\section{Materials and Methods}

Plant material. The 20 clonal accessions used in this study were selected from the creeping bluegrass breeding collection at the University of Minnesota. They were chosen to include accessions with similar, unknown, and diverse lineages. Included among the chosen accessions were $17 P$. annua var. reptans (13 tetraploids and four diploids), one $P$. annua var. annua (tetraploid), and two outliers: one $P$. supina and one $P$. trivialis (Table 1). All of the tetraploid $P$. annua var. reptans accessions were $\mathrm{F}_{5}, \mathrm{~F}_{6}$, or $\mathrm{F}_{7}$ selections.

DNA isolation. DNA was extracted from not fully expanded leaf and sheath tissue using the Qiagen Plant DNeasy Mini Kit (Qiagen Inc., Valencia, Calif.) with minor modifications to the manufacturer's suggested protocol. Immediately following collection, $150 \mathrm{mg}$ of plant tissue was placed in a 2-mL microcentrifuge tube and stored at $-80^{\circ} \mathrm{C}$. The tissue was ground in the same tube in which it was stored. Buffer AP1, RNase A, and a small amount of carborundum (used to aid in the disruption of cells during the grinding process) were added to the tissue and ground manually for 2 min using a glasstipped micropestle. The tube was vortexed and then placed on ice until a number of samples had been ground, and then the Qiagen protocol was followed. The extracted DNA was quantified using the Hoefer DyNA Quant 200 fluorometer (Hoefer, San Francisco, Calif.).

Primers. Primers 801-850, from primer set \#9, obtained from the University of British Columbia (UBC, Biotechnology Laboratory, University of British Columbia, Vancouver, British Columbia, Canada) were screened to determine potential usefulness. Twelve primers (Table 2) were selected from the initial screening, 11 of which were chosen on the basis of the number of fragments, fragment intensity, and fragment separation; the twelfth primer (UMN001) had the tag on the $5^{\prime}$ side of the repeat. Primers were newly synthesized by Integrated DNA Technologies (IDT, Coralville, Iowa) for use in the study.

$P C R$. Two DNA samples from the same plant of each accession were collected, extracted independently, and used in separate PCR reactions. The reaction mixture $(25 \mu \mathrm{L}$ total volume) consisted of $1 \mathrm{U}$ of AmpliTaq DNA polymerase (PerkinElmer; Wellesley, Mass.), $1 \times$ ThermoPol PCR reaction buffer $\left(10 \mathrm{~mm} \mathrm{KCl}, 10 \mathrm{~mm}\left(\mathrm{NH}_{4}\right)_{2} \mathrm{SO}_{4}, 20 \mathrm{~mm}\right.$ Tris- $\mathrm{HCl}(\mathrm{pH} 8.8), 2 \mathrm{~mm} \mathrm{MgSO}_{4}, 0.1 \%$ Triton X-100) (New England BioLabs Inc., Ipswich, Mass.), $0.2 \mathrm{~mm}$ of each dNTP,

Table 1. Poa accessions, ${ }^{\mathrm{z}}$ chromosome number, and origin.

\begin{tabular}{lll}
\hline Accession & Putative ploidy level & \multicolumn{1}{c}{ Origin/lineage } \\
\hline P. annua var. reptans & & \\
UMN10184 & Tetraploid & Long Island, N.Y. \\
UMN11930 & Diploid & Edina Country Club, Minn. \\
UMN14745 & Tetraploid & Seedling from 10184 \\
UMN14838 & Tetraploid & Seedling from 10184 \\
UMN13979 & Tetraploid & Unknown cross, sibling of UMN14199 \\
UMN14199 & Tetraploid & Unknown cross, sibling of UMN13979 \\
UMN10234 & Tetraploid & Les Bolstad Golf Course, Minn. \\
UMN14045 & Tetraploid & $10184 \times 10234$ \\
UMN14524 & Tetraploid & $10042 \times 10234$ \\
UMN13820 & Diploid & Columbia Country Club, Md. \\
UMN14577 & Diploid & Minnesota \\
UMN14080 & Tetraploid & New York \\
UMN14383 & Diploid & Research green K-11, Minnesota \\
UMN14833 & Diploid & Research green K-3, Minnesota \\
UMN14232 & Tetraploid & $13979 \times 10042$ \\
UMN13834 & Tetraploid & Columbia Country Club, Md. \\
UMN13861 & Tetraploid & $12167 \times 10042$ \\
P. annua var. annua & & \\
UMN12283 & Tetraploid & Southern United States \\
P. supine & & \\
UMN13859 & Diploid & Unknown \\
P. trivialis & & \\
UMN14404 & Diploid & Research green K-11, Minnesota \\
\hline
\end{tabular}

${ }^{2}$ All of the tetraploid P. annua var. reptans accessions were $\mathrm{F}_{5}, \mathrm{~F}_{6}$, or $\mathrm{F}_{7}$ selections.

${ }^{\mathrm{y}}$ Chromosome number was attributed to each accession based upon phenotypic descriptions as noted by Velguth and White (1993).

Table 2. ISSR primers used in performing PCR.

\begin{tabular}{|c|c|c|c|c|c|c|c|}
\hline \multirow[b]{2}{*}{ Primer } & \multicolumn{4}{|c|}{ All accessions ${ }^{z}$} & \multicolumn{3}{|c|}{ P. аппиа accessions } \\
\hline & Sequence $5^{\prime} \rightarrow 3^{\prime y}$ & $\mathrm{TF}$ & $\mathrm{TP}$ & $\mathrm{PP}$ & $\mathrm{TF}$ & $\mathrm{TP}$ & $\mathrm{PP}$ \\
\hline$\overline{\mathrm{UBC}} 809$ & $(\mathrm{AG})_{8} \mathrm{G}$ & & & & & & \\
\hline UBC 823 & $(\mathrm{TC})_{8} \mathrm{C}$ & & & & & & \\
\hline UBC825 & $(\mathrm{AC})_{8} \mathrm{~T}$ & 3 & 3 & 1.00 & 1 & 1 & 1.00 \\
\hline UBC 827 & $(\mathrm{AC})_{8} \mathrm{G}$ & 4 & 4 & 1.00 & 2 & 1 & 0.50 \\
\hline UBC 829 & $(\mathrm{TG})_{8} \mathrm{C}$ & & & & & & \\
\hline UBC834 & $(\mathrm{AG})_{8} \mathrm{YT}$ & & & & & & \\
\hline UBC 836 & $(\mathrm{AG})_{8} \mathrm{YA}$ & 3 & 2 & 0.67 & 2 & 1 & 0.50 \\
\hline UBC841 & $(\mathrm{GA})_{8} \mathrm{YC}$ & 5 & 5 & 1.00 & 2 & 1 & 0.50 \\
\hline UBC 848 & $(\mathrm{CA})_{8} \mathrm{RG}$ & 3 & 3 & 1.00 & 1 & 0 & 0.00 \\
\hline UBC849 & $(\mathrm{GT})_{8} \mathrm{YA}$ & 3 & 3 & 1.00 & 2 & 2 & 1.00 \\
\hline UBC 850 & $(\mathrm{GT})_{8} \mathrm{YC}$ & 10 & 10 & 1.00 & 7 & 6 & 0.86 \\
\hline UMN001 & $\mathrm{CA}(\mathrm{GT})_{8}$ & 7 & 7 & 1.00 & 5 & 5 & 1.00 \\
\hline Total & & 38 & 37 & 0.96 & 22 & 17 & 0.77 \\
\hline
\end{tabular}

${ }^{\mathrm{z}}$ Total reproducible fragments (TF), total polymorphic fragments (TP), and proportion of polymorphic fragments (PP) for all accessions and $P$. annua accessions alone.

${ }^{\mathrm{y}} \mathrm{Y}=\mathrm{C}$ or $\mathrm{T}$ and $\mathrm{R}=\mathrm{A}$ or $\mathrm{G}$.

$0.3 \mu \mathrm{M}$ of a single primer, and $15 \mathrm{ng}$ of DNA. PCR amplifications were performed on a Hybaid Omnigene thermocycler (Thermo Electron Corp., Waltham, Mass.) or an MJ Research PTC-150 Minicycler thermocycler (Bio-Rad Laboratories Inc., Waltham, Mass.) using the following program: initial denature for $7 \mathrm{~min}$ at $94{ }^{\circ} \mathrm{C}, 35$ cycles of $1 \mathrm{~min}$ at $94{ }^{\circ} \mathrm{C}, 2$ min at $52{ }^{\circ} \mathrm{C}, 2 \mathrm{~min}$ at $72{ }^{\circ} \mathrm{C}$, and a final extension of $7 \mathrm{~min}$ at $72^{\circ} \mathrm{C}$.

Electrophoresis and data analysis. Five microliters of $6 \times$ loading buffer $(0.25 \%$ bromophenol blue, $0.25 \%$ xylene cyanol FF, 30\% glycerol) was added to each PCR reaction, $20 \mu \mathrm{L}$ of the diluted reaction was loaded on a $2 \%$ agarose gel, and samples were electrophoresed at $6.5 \mathrm{~V} / \mathrm{cm}$ for $4 \mathrm{~h}$ with TAE buffer. Amplified products were detected by staining with ethidium bromide, and gels were photographed using a Bio-Rad Gel Doc 2000 digital imaging system and Quantity One, version 4.0.3, software (Bio-
Rad Laboratories Inc., Hercules, Calif.). Gel images were printed with a thermal printer and scored visually for the presence or absence of amplified fragments in the range of 300-1300 bp. The ISSR fragments were considered to be dominant markers (Wolfe and Liston, 1998) and were scored as 1 (present) or 0 (absent). A similarity matrix was calculated using the correlation coefficient and used to construct a dendrogram by the unweighted pair group method (UPGMA) using the SAHN-clustering and TREE programs from NTSys version 2.02 (Exeter Software, Setauket, N.Y.).

\section{Results and Discussion}

The initial ISSR primer screening investigated 50 primers with varying results. Eighteen of the primers produced no amplified fragments, and 12 of these were primers that contained AT repeats. Nagaoka and Ogihara 
(1997) found a similar result and concluded that, at the high annealing temperature used $\left(52{ }^{\circ} \mathrm{C}\right)$, primers with AT repeats were probably unable to anneal to the DNA. Faint fragments were produced by six primers and deemed unreliable. The remaining 26 primers produced at least one easily scored fragment, with some also producing faint fragments. Eleven of these 26 primers were selected for use in the full study (Table 2). These 11 were selected because they had the greatest number of fragments with good separation between the fragments, which would aid in scoring. In addition, a twelfth primer (UMN001) was designed and used to test the utility of a primer that had the tag on the $5^{\prime}$ side of the repeat. The use of the 12 selected primers in the full study found that primers UBC809, UBC823, UBC829, and UBC834 produced fragments that had inconsistent amplification and were not included in data analysis, while the remaining eight (UBC825, UBC827, UBC836, UBC841, UBC848, UBC849, UBC850, UMN001) produced reproducible fragments and were used to create a similarity matrix (not shown) and the dendrogram (Fig. 1) for the $20 \mathrm{Poa}$ accessions.

Eight primers produced a total of 38 fragments, of which 16 were exclusive to $P$. supina or $P$. trivialis (Table 2 ). The remaining 22 fragments were used in differentiating the creeping bluegrass accessions. Among these 22 fragments, 17 (77.3\%) were found to be polymorphic. Primers UBC849, UBC850, and UMN001 all contained GT repeats and produced 14 fragments, of which 13 were polymorphic and made up over $75 \%$ of the total polymorphic fragments. These three GT repeats had sufficient resolution to distinguish all but two of the creeping bluegrass accessions (Table 2 and Fig. 1).

The dendrogram (Fig. 1) shows that $P$. supina and $P$. trivialis were both grouped away from the creeping bluegrass accessions. $P$. supina was somewhat similar to the creeping bluegrass accessions with a similarity coefficient of 0.20 ; however, with these primers, $P$. trivialis showed no similarity with a similarity coefficient of zero. In general, the clustering within the dendrogram agreed with the known lineage (Table 1) of the creeping bluegrass accessions used in this study and was divided into two main clusters (A and $\mathrm{B}$ ).

Cluster A (Fig. 1) consisted of four subclusters that had a high degree of relatedness within each subcluster (see Table 1 for pedigrees). In subcluster $A_{1}$, three of the four accessions are closely related; UMN14745 and UMN14838 were sibling selections from recurrent selfing from UMN10184. However, the fourth accession, UMN11930, was an unexpected addition to this subcluster. Its origin and unique phenotypic characteristics of nonflowering and thick, somewhat curled leaves are different from UMN10184.

Subcluster $\mathrm{A}_{2}$ confirmed the known pedigrees; UMN14199 and UMN13979 are very closely related, siblings from the same cross of unknown parents. Although closely

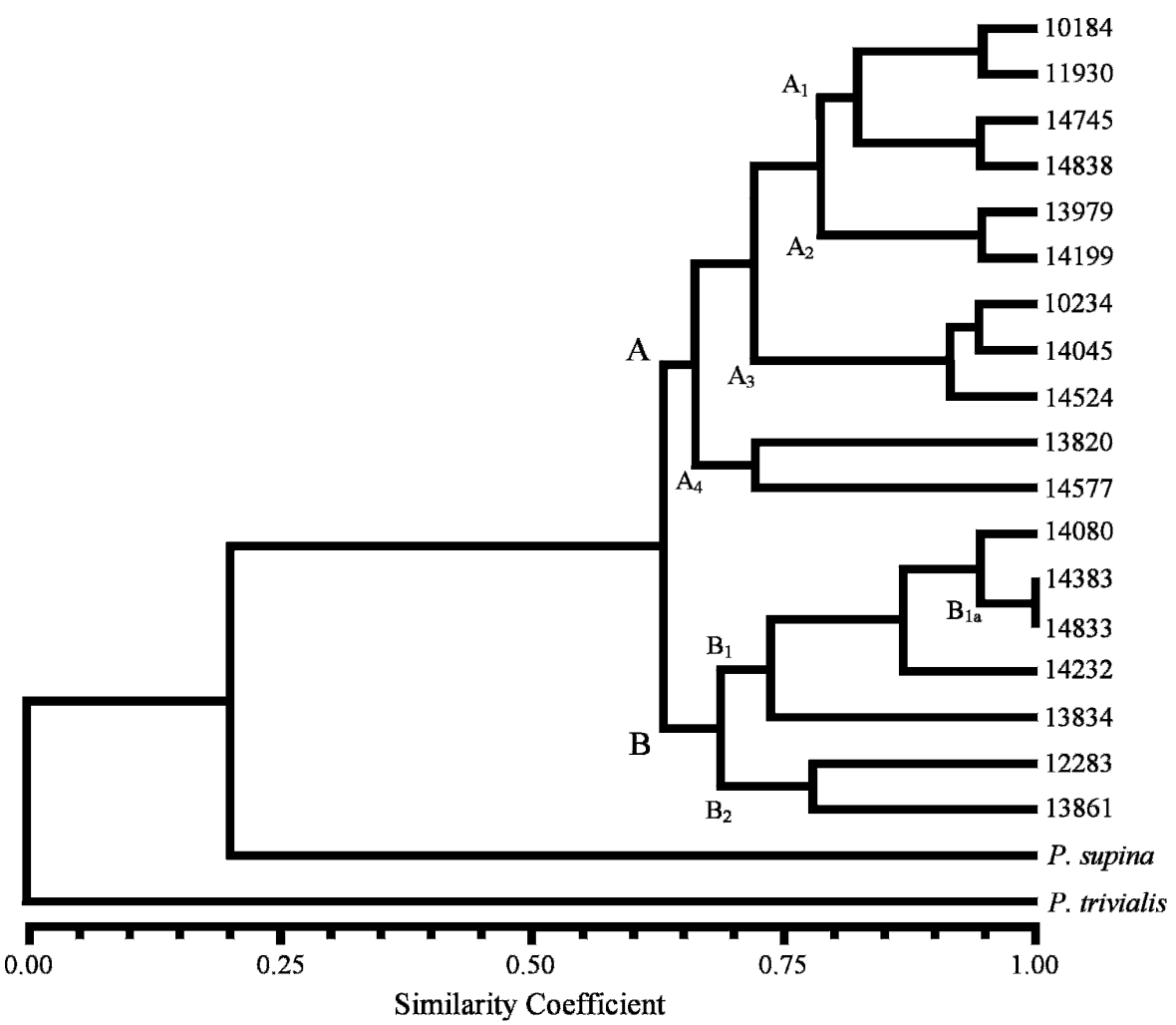

Fig. 1. Dendrogram derived from a UPGMA cluster analysis of 38 ISSR fragments showing the relatedness among 20 Poa accessions.

related, these two accessions were distinguishable by ISSR PCR. The accessions branched from a higher subbranch along with the subcluster that contains UMN10184, a parent often used for making crosses within the breeding project. These data may indicate that one of the parents of these two accessions was UMN10184.

UMN14045, UMN14524, and their common paternal parent UMN10234 comprised subcluster $\mathrm{A}_{3}$. Phenotypically, the two progeny are quite different from their paternal parent UMN10234 (Fig. 2A and B). This genetic similarity coupled with phenotypic dissimilarity may represent the potential for particular alleles, which are not necessarily exhibited phenotypically, to accumulate during the process of recurrent selfing and selection. Alternatively, there may be one or a very limited number of polymorphic alleles with major phenotypic effects not associated with the molecular polymorphisms.

Subcluster $\mathrm{A}_{4}$ was composed of UMN13820 and UMN14577, two accessions from different geographic origins. However, they have two significant phenotypic characteristics in common; they are both ultradwarf and diploid (Fig. 2C, D, and E). The grouping of these two accessions is quite remarkable and demonstrates that two accessions collected from distant geographic regions may possess genetic similarities.

In contrast to cluster $\mathrm{A}$, cluster $\mathrm{B}$ is a group of accessions that possess little or no pedigree commonality but can be divided into sub- clusters $\mathrm{B}_{1}$ and $\mathrm{B}_{2}$. Subcluster $\mathrm{B}_{1}$ contains five accessions of unrelated lineages, including two diploid accessions that were genotypically indistinguishable (subbranch $\mathrm{B}_{1 \mathrm{a}}$ ) with the ISSR primers that were used in this study. One possible reason for the difficulty in differentiating these two accessions may be their similar origin (Table 1); UMN14383 and UMN14833 were collected from two different research greens separated by $\approx 100 \mathrm{~m}$, but because of their close proximity, it is possible that they are the same clone.

Subcluster $\mathrm{B}_{2}$ consists of two accessions that originated from very different sources (Table 1) yet have some similar phenotypic characteristics; UMN12283 is an annual, and UMN13861 has some annual-like characteristics: more bunch-type growth habit, shorter prereproductive period, and decreased disease resistance.

It appears that there may be an association between the ISSR fragments and morphological or life-history traits. Subclusters $\mathrm{A}_{4}, \mathrm{~B}_{1 \mathrm{a}}$, and $\mathrm{B}_{2}$ each consisted of pairs of unrelated accessions, usually originating from diverse locations, which had common phenotypes and ISSR fragments. More fragments would be needed to better establish the degree of genetic relatedness; however, an association such as this was seen with barley (Fernandez et al., 2002), where the winter and spring habit types clustered independently of each other, even when from diverse genetic lineages.

Ideally, the most efficient genotyping would employ unique fragments for each 

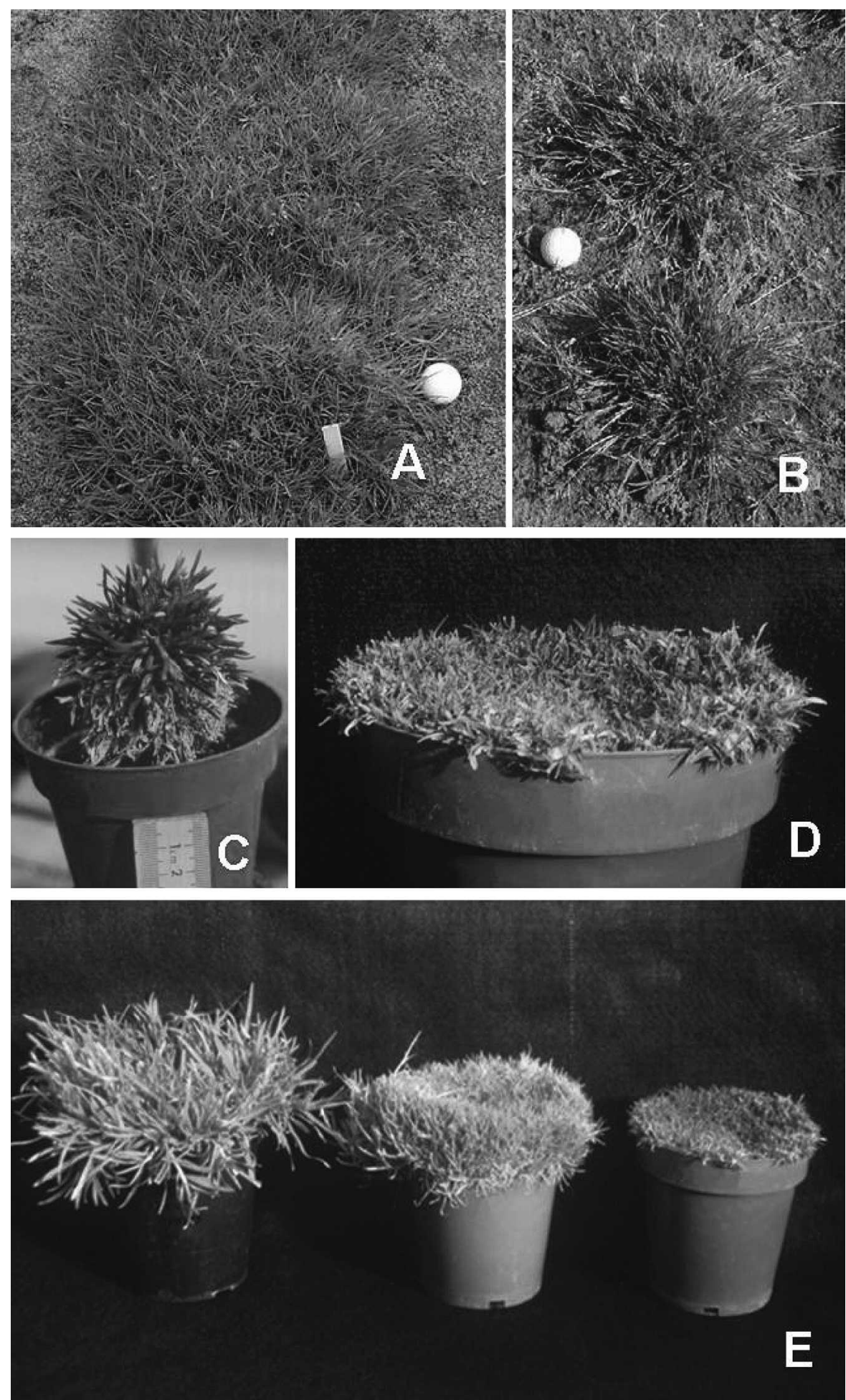

Fig. 2. Two members of subcluster $A_{3}$ showing some of the phenotypic differences between UMN14524 (A) and its paternal parent UMN10234 (B). Each plant was derived from a single seed and was $\approx 120 \mathrm{~d}$ old. Plants are unmown and golf ball is pictured for scale. (C) Ultra-dwarf diploid, UMN14577 in a standard $7.6 \mathrm{~cm}$ pot, unmown. (D) Close-up of ultra-dwarf diploid, UMN13820 in a standard $15 \mathrm{~cm}$ pot, unmown. (E) Visual representative comparison of typical, dwarf, and ultra-dwarf forms of creeping bluegrass. Left to right: typical perennial tetraploid; dwarf tetraploid, UMN13834; and ultradwarf diploid, UMN13820. All are unmown in standard $15-\mathrm{cm}$ pots

accession using one primer. The reported number of unique fragments in other studies using ISSR PCR has been highly variable. Mattioni (2002) found nine unique fragments using 45 primers for 124 cultivars of Notho- fagus species, and Fernandez et al. (2002) found 34 unique fragments using 10 primers for 14 cultivars of barley. Although unique fragments are desirable, there can be limitations to their usefulness. Most studies inves- tigate only a limited number of cultivars, and as other cultivars are investigated, the unique fragments may be found to occur in other genotypes. Among the amplified PCR products in the current study, two unique fragments were found for two of the more unique accessions. One for UMN12283 using primer UMN001 (Fig. 3A), and another for UMN14577 using primer UBC841 (Fig. 3B).

Primers UBC 841 and UBC 848 provided only interspecies and no intraspecies differences except for the single unique fragment mentioned previously for primer UBC841. In contrast, among other primers was the presence of some fragments common to all $P$. annua accessions and $P$. supina, and one fragment present in all three species ( $P$. annua, $P$. supina, and $P$. trivialis). The presence of common fragments in these three species could be explained in one of two ways: either different fragments of the same size are being independently amplified and appear to be the same product, or some loci have been highly conserved across different $P o a$ species. If the latter were true, it could mean that ISSR PCR sometimes amplifies important and therefore conserved genomic regions. The amplification of such regions could aid in the identification of the function of a region. Pasakinskiene et al. (2000) found no evidence that functional coding regions were amplified; however, Kojima et al. (1998) state that ISSR fragments may mark gene-rich regions.

Because there are no published microsatellite markers for $P$. annua, and they are rarely transferable from other species, the amplified fragments from this study could be sequenced and used to develop microsatellite markers as van der Nest et al. (2000) successfully did with Eucalyptus. Unlike ISSR markers, microsatellites are codominant markers, which can be extremely valuable for heritability and QTL studies and markerassisted selection.

\section{Summary and Conclusions}

ISSR PCR produced highly polymorphic amplification products that allowed for the differentiation of all but two Poa accessions using as few as three primers. Parents, progeny, and closely related accessions were easily distinguishable from one another. The ISSR data also clearly illustrated relationships among the accessions, grouping $P$. trivialis and $P$. supina away from the creeping bluegrass accessions and forming clusters that generally agreed with known lineage.

ISSR PCR can be used as a simple, fast, and relatively inexpensive method to produce useful DNA fragments in creeping bluegrass. It could be useful for cultivar identification, seed certification, and identification of turfgrass species. It also offers the possibility of developing microsatellite markers. Finally, it is a robust method for identifying polymorphic loci that could be used in the study of genetic relatedness, heritability or linkage to 


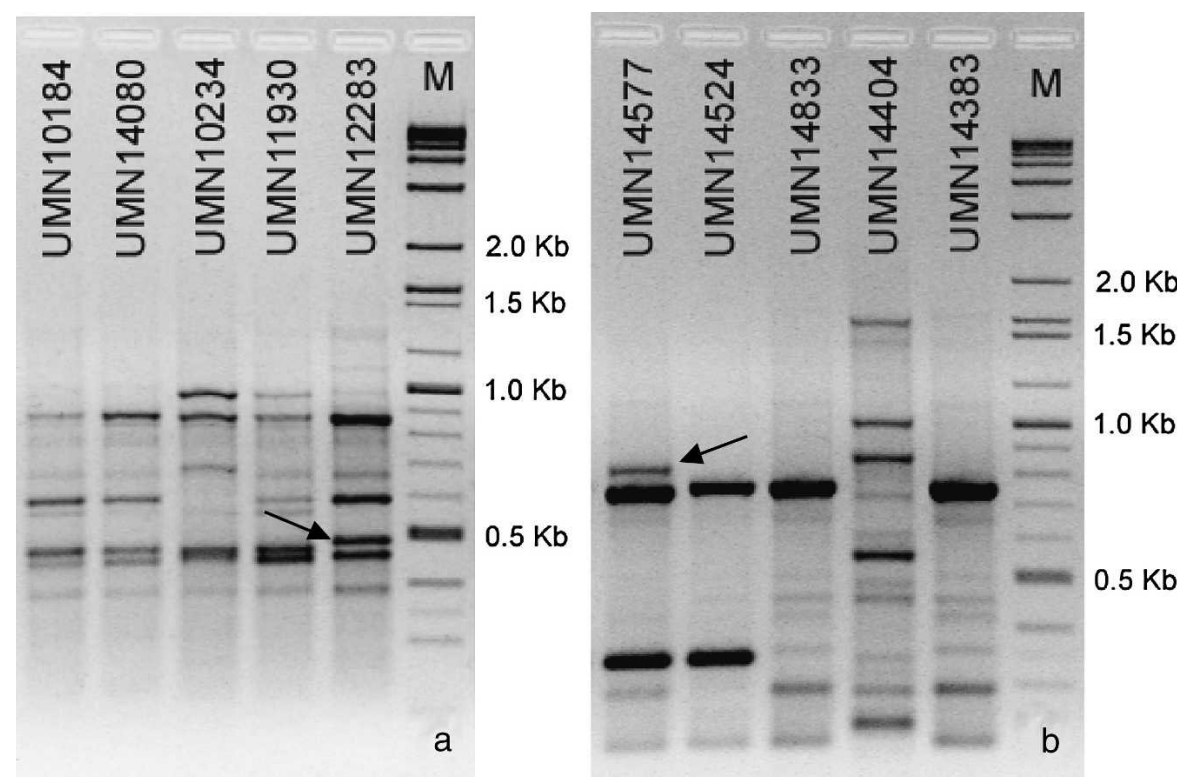

Fig. 3. Negative images of ethidium bromide stained agarose gels showing unique fragments found for two of the accessions (arrows): (A) unique fragment for UMN12283 using primer UMN001; (B) unique fragment for UMN14577 using primer UBC841.

important traits, development of linkage maps, and marker-assisted breeding.

\section{Literature Cited}

Adams, W.A. and P.J. Bryan. 1980. Variations in the growth and development of annual bluegrass populations selected from seven different sports turf areas, p. 109-115. In: Proc. Int. Turfgrass Res. Conf., 3rd, Munich, Germany 11-13 July 1980. Amer. Soc. Agron., Madison, Wis.

Bailey, R. 1948. The home garden self-pronouncing dictionary of plant names, p. 64. The American Garden Guild, Inc., New York, N.Y

Baker, S.W., P.D. Hind, T.A. Lodge, J.A. Hunt, and D.J. Binns. 1995. A survey of golf greens in Great Britain. II. Sward characteristics. J. Sports Turf Res. Inst. 71:23-30.

Beard, J.B. 1970. The plant characteristics, dissemination, environmental adaptation, and cultural requirements of Pоа аппиа L. Razen Turf Gazon. 2:33-35.

Beard, J.B., P.E. Rieke, A.J. Turgeon, and J.M. Vargas, Jr. 1978. Annual bluegrass (Poа апnиа L.): description, adaptation, culture and control. Res. Rep. 352. Mich. State Univ. Agric. Exp. Stn., East Lansing.

Beard, J.B. 1999. Pоа апnиа terminology clarified. Turfax 7(4):3.

Cline, V.W. 2001. Population dynamics of Poa аппиа L. on a northern golf course. Univ. of Minnesota, Ph.D. Diss.

Darmency, H., A. Berti, J. Gasquez, and A. Matejicek. 1992. Association of esterase isozymes with morphology in F2 progenies of two growth variants in Poa annиa L. New Phytol. 121:657-661.

Darmency, H. and J. Gasquez. 1997. Spontaneous hybridization of the putative ancestors of the allotetraploid Poa annua. New Phytol. 136:497-501.

Fernandez, M.E., A.M. Figueiras, and C. Benito. 2002. The use of ISSR and RAPD markers for detecting DNA polymorphism, genotype identification and genetic diversity among barley cultivars with known origin. Theor. Appl. Genet. 104:845-851.

Gibeault, V.A. 1971. Perenniality in Poa аппиа L. Oregon State Univ., Ph.D. Diss.

Heide, O.M. 2001. Flowering responses of contrasting ecotypes of Poa аппиа and their putative ancestors Poa infirma and Poa supina. Ann. Bot. (Lond.) 87:795-804.

Huff, D.R. 1999. Managing Poа аппиа greens. Grounds Maint. 34(1):13-14, 16.

Johnson, P.G., B.A. Ruemmele, P. Velguth, D.B. White, and P.D. Ascher. 1993. An overview of Poa аппиа L. reproductive biology. Int. Turfgrass Soc. Res. J. 7:798-804.

Kamp, I.H.A. 1981. Annual meadow-grass (Poa annua) - a Dutch viewpoint. J. Sports Turf Res. Inst. 57:41-48.

Kantety, R.V., X.P. Zeng, J.L. Bennetzen, and B.E. Zehr. 1995. Assessment of genetic diversity in Dent and Popcorn (Zea mays L.) inbred lines using inter-simple sequence repeat (ISSR) amplification. Mol. Breed. 1:365-373.

Kind, M. 1997. For sale: Poа аппиа seed? Golf Course Mgt. 65(11):48.

Kojima, T., T. Nagaoka, K. Noda, and Y. Ogihara 1998. Genetic linkage map of ISSR and RAPD markers in Eikorn wheat in relation to that of RFLP markers. Theor. Appl. Genet. 96:37-45.

Law, R., A.D. Bradshaw, and P.D. Putwain. 1977. Life-history variation in Poa annua. Evolution 31:233-246.

Mattioni, C., M. Casasoli, M. Gonzalez, R. Ipinza, and F. Villani. 2002. Comparison of ISSR and RAPD markers to characterize three Chilean Nothofagus species. Theor. Appl. Genet. 104:1064-1070.

Mengistu, L.W., G.W. Mueller-Warrant, and R.E. Barker. 2000. Genetic diversity of Pоа аппиа in western Oregon grass seed crops. Theor. Appl. Genet. 101:70-79.

Nagaoka, T. and Y. Ogihara. 1997. Applicability of inter-simple sequence repeat polymorphisms in wheat for use as DNA markers in comparison to RFLP and RAPD markers. Theor. Appl. Genet. 94:597-602.

Nannfeldt, J.A. 1937. The chromosome numbers of Poa, sect. Ochlopoa A and Gr. and their taxonomical significance. Botan. Notiser 1937:238-254.

Pasakinskiene, I., C.M. Griffiths, A.J.E. Bettany, V. Paplauskiene, and M.W. Humphreys. 2000. Anchored simple-sequence repeats as primers to generate species-specific DNA markers in Lolium and Festuca grasses. Theor. Appl. Genet. 100:384-390

Prevost, A. and M.J. Wilkinson. 1999. A new system of comparing PCR primers applied to ISSR fingerprinting of potato cultivars. Theor. Appl. Genet. 98:107-112.

Sprague, H.B. and G.W. Burton. 1937. Annual bluegrass (Poa annua L.), and its requirements for growth. New Jersey Agr. Exp. Stn. Bull. 630 .

Sweeney, P.M. and T.K. Danneberger. 1995 RAPD characterization of Роа аппиа L. populations in golf course greens and fairways. Crop Sci. 35:1676-1680.

Timm, G. 1965. Biology and systematics of Poa annua. Z. Acker. Pflanzenbau 122:267-294.

Tsumura, Y., K. Ohba, and S.H. Strauss. 1996. Diversity and inheritance of inter-simple sequence repeat polymorphisms in Douglas-fir (Pseudotsuga menziesii) and sugi (Cryptomeria japonica). Theor. Appl. Genet. 92:40-45.

Tutin, T.G. 1952. Origin of Poa aпnиа L. Nature 169:160.

Tutin, T.G. 1957. A contribution to the experimental taxonomy of Poа аппиа L. Watsonia $4: 1-10$

van der Nest, M.A., E.T. Steenkamp, B.D. Wingfield, and M.J. Wingfield. 2000. Development of simple sequence repeat (SSR) markers in Eucalyptus from amplified inter-simple sequence repeats (ISSR). Plant Breed. 119:433-436.

Velguth, P.H. and D.B. White. 1993. The relative frequency of diploid and tetraploid Роа аппиа L. on selected golf courses in Minnesota, p. 165. In: 1993 Agronomy Abstracts. ASA, Madison, WI.

Warwick, S.I. and D. Briggs. 1978a. The genecology of lawn weeds. I. Population differentiation in Poa annua L. in a mosaic environment of bowling green lawns and flower beds. New Phytol. 81:711-723.

Warwick, S.I. and D. Briggs. 1978b. The genecology of lawn weeds. II. Evidence for disruptive selection in Poa annua L. in a mosaic environment of bowling green lawns and flower beds. New Phytol. 81:725-737.

Wolfe, A.D. and A. Liston. 1998. Contributions of PCR-based methods to plant systematics and evolutionary biology, p. 43-86. In: D.E. Soltis, P.S. Soltis, and J.J. Doyle (eds.). Plant molecular systematics II. Kluwer, Boston.

Wu, L., I. Till-Bottraud, and A. Torres. 1987. Genetic differentiation in temperatureenforced seed dormancy among golf course populations of Poa annua L. New Phytol. 107:623-631.

Zietkiewicz, E., A. Rafalski, and D. Labuda. 1994. Genome fingerprinting by simple sequence repeat (SSR)-anchored polymerase chain reaction amplification. Genomics 20:176-183. 